\title{
SeleKCJA ARCHIWALNA JaKo KONSTRUOWANIE ZASOBU ŹRÓDEŁ HISTORYCZNYCH
}

\begin{abstract}
A rchiwa dla historii czy dla pamięci? Na to pytanie można odpowiedzieć - Linaczej: jedynym uprawnionym interpretatorem przeszłości jest historyk - nie publicysta, polityk czy sąd, jak zdarza się ostatnio. Dlatego w archiwach powinni pracować archiwiści przygotowani do tego na studiach historycznych (obdarzeni wrażliwością historyczną), a selekcja archiwalna powinna odbywać się na zamówienie środowisk historyków zawodowych. A jak jest obecnie? Czy historyk jest zadowolony z wyników selekcji archiwalnej?

Zagadnienie selekcji archiwalnej jest kluczowe dla pracy historyka, choć niekoniecznie (a powinien) zdaje on sobie sprawę z jej istnienia, jako że przez ostatnie półwiecze stanowiła ona niemal wyłącznie pole działania archiwistów, a przedtem (do czego wielu historyków przywykło) o stanie zachowania decydował los, a nie świadoma działalność człowieka.

Tymczasem refleksja nad spuścizną źródłową wydaje się niezbędna do poprawnego i kompleksowego oddania charakteru danego podmiotu funkcjonującego w przeszłości oraz obrazu życia społecznego, tworzonego przez ów podmiot i jemu podobne. Ba, do wiedzy, czy ten charakter w ogóle można
\end{abstract}


oddać! Pozostaje zatem zadać pytanie, czy utrzymanie status quo w zakresie selekcji archiwalnej jest korzystne również w realiach początku XXI w. Pytanie i kryjąca się za nim wątpliwość są tym bardziej zasadne, że wyniki selekcji wykazują znaczny stopień redundancji informacji, a mimo to nie pozwalają na jej weryfikację, ponieważ są to zwykle materiały pochodzące z jednego źródła - najczęściej nie materiał pierwotny, ale pochodny. Ten stan jest wynikiem błędów i niechlujności w procesie selekcji. Wiele można by w tym miejscu napisać o patologiach występujących w łonie służby archiwalnej.

Pewne zaniechania są zauważalne już na etapie selekcji aktotwórców. Służba archiwalna ogranicza się do realizacji nakazów, tracąc zainteresowanie całym spektrum swojej misji. Tymczasem to nie ułomny i szybko dewaluujący się zapis prawny, ale właśnie misja jest powodem i istotą działalności archiwów. Praktycznie archiwa nawet się nie zastanawiają, którzy aktotwórcy niepodlegający nadzorowi archiwalnemu wytwarzają źródła warte wieczystego zachowania. Czy jest to wada systemowa? Błędy w doborze kadr archiwów? Czy może błędy w polityce archiwalnej, już na najniższym poziomie pracy na przedpolu archiwalnym? Jedno jest pewne: spuścizny, registratury stowarzyszeń, fundacji, przedsiębiorstw itp. trafiają do archiwów w znikomym procencie i raczej nie dzieje się to z inicjatywy archiwów. Nic nie tłumaczy takiego zaniechania teraz i nie będzie żadnego wytłumaczenia dla przyszłych pokoleń. Czy zatem idea narodowego zasobu archiwalnego jest tylko mrzonką? Czy nie czas spojrzeć holistycznie na system archiwów państwowych, a nie kreować politykę promocji poszczególnych jego elementów, które - dodane nie sumują się w całość, jakiej oczekiwaliby historycy?

W teorii archiwalnej oraz metodyce pracy archiwów wieczystych wyróżniamy dwa rodzaje selekcji archiwalnej: selekcję aktotwórców, mającą na celu wybór jednostek organizacyjnych, których spuścizna aktowa zasługuje na trwałe przechowywanie, oraz selekcję wytworzonej przez nie dokumentacji, co oznacza wyłonienie materiałów archiwalnych z całej spuścizny kancelaryjnej podmiotu zakwalifikowanego na etapie pierwszym jako wytwarzający dokumentację o wartości historycznej ${ }^{1}$.

Selekcja archiwalna jako prerogatywa pracowników archiwów państwowych jest wynikiem zjawiska masowości produkcji aktowej, które można obserwować od drugiej połowy XX w. Konstatacja tego zjawiska oraz jego wpływ na bazę źródłową historyków stały się podstawą wielu analiz doty-

1 Polski stownik archiwalny, red. W. Maciejewska, Warszawa 1974, s. 76. 
czących polityki archiwalnej z nim związanej ${ }^{2}$. Skoro masowość produkcji akt uniemożliwia zachowanie wszystkiego - postanowiono zachować tylko jej niezbędną część. Jaką? O tym właśnie miała decydować selekcja. W ten sposób wypracowano w Polsce kanon kryteriów stosowanych przy selekcji archiwalnej, wśród których standardowo są wymieniane:

- w fazie pierwszej: pochodzenie, typowość, unikatowość;

- w fazie drugiej: treść, dawność, cechy zewnętrzne, sposób wykonania, stan zachowania ${ }^{3}$.

W swoich rozważaniach podczas poprzedniego, XVII Powszechnego Zjazdu Historyków Polskich w Krakowie, Halina Robótka wskazała, że spuścizna aktowa dzisiejszych kancelarii będzie wynikiem trzech czynników: 1) zasad i metod selekcji, 2) kryteriów selekcji oraz 3) archiwistów, którzy je będą stosować . Wypada nam, niestety, zgodzić się z tym stwierdzeniem. „Niestety”, gdyż metody i kryteria selekcji archiwalnej wypracowane w ostatnim półwieczu przez teoretyków archiwistyki odnoszą się wyłącznie do realiów PRL-u, kiedy - jak przyznaje Robótka - „wszystko było państwowe i państwowej poddane kontroli”.

Nie docenialibyśmy tej konstatacji. Stoi za nią bowiem nie tylko kwestia ustroju, ale także świadomości. Pytanie brzmi: czy pogodziliśmy się już z odejściem od dwudziestowiecznego „romantyzmu budów” z widokiem na „geometryczne lasy kominów fabrycznych... stalowe, antynaturalistyczne rżenie milionów koni mechanicznych... maszyny, jeszcze raz maszyny i tłumy”, jak to opisywał młody twórca z rocznika Kolumbów ${ }^{6}$, przewidując nadejście ponowoczesności, koniec kolektywnego życia i dyktatu industriali-

2 Zob. choćby: B. Schwineköper, Zagadnienie masowości akt w archiwach, Archeion, t. 25, 1956, s. 221-235; B. Kroll, Uwagi w sprawie rozmiarów narastającego zasobu archiwalnego i ich wptyw na perspektywy dziatalności archiwów, Archeion, t. 57, 1972, s. 75-84; B. Ryszewski, Problemy i metody badawcze archiwistyki, Toruń 1985, s. 28-35; Z. Chmielewski, Metodyczne aspekty wartościowania akt, Archeion, t. 82, 1987, s. 20-42; tenże, Archiwistyka wobec problemu masowości akt wspótczesnych, Archeion, t. 100, 1999, s. 51-68.

3 Zob. np. Kancelaria i archiwum zaktadowe, red. Z. Pustuła, Warszawa 2006, s. $45-46$.

${ }^{4}$ H. Robótka, Zasady i metody selekcji dokumentacji tradycyjnej i elektronicznej a potrzeby badań obecnych $i$ przysztych, http://jazon.hist.uj.edu.pl/zjazd/materialy/robotka. pdf [dostęp 5 grudnia 2011 r.], s. 1.

5 Tamże.

${ }^{6}$ A. Trzebiński, Korzenie i kwiaty myśli wspótczesnej, [w:] Aby podnieść różę, Warszawa 1999, s. 50. Andrzej Trzebiński - trzeci redaktor pisma kulturalnego „Sztuka i Naród” wychodzącego w Warszawie podczas ostatniej okupacji niemieckiej. Rozstrzelany w ulicznej egzekucji w 1943 r. 


\section{Artur Górak, Dariusz Magier}

zmu? Czy też może nadal odbieramy świat, kierując się heglowskim historycyzmem, i chcemy przedstawiać dzieje na podstawie historii politycznej, nie przyjmując do wiadomości, że tzw. historia ludzkości to zaledwie „historia władzy politycznej”, klucz administracyjny selekcji dokumentacji (w naszym przypadku - nadreprezentacyjność źródeł administracyjnych w spuściźnie archiwalnej) to zaś - zgodnie z Popperowskim spostrzeżeniem - efekt tego, że „ludzie mają skłonność do kultu władzy”7.

Stąd w przeszłości można było dywagować o profesjonalizmie służby archiwalnej, w której ręku znajdowała się pełnia władzy, jeśli chodzi o kształt archiwalnego dziedzictwa narodowego, czy o kolejnych prawnych sposobach poddawania coraz ściślejszej kontroli już nie tylko archiwów zakładowych, ale i kancelarii jednostek organizacyjnych. Wprowadzanie owej „dyktatury archiwalnej"8 od 1990 r. było odwrotnie proporcjonalne do wielkości pola operacyjnego archiwów państwowych. W ciągu minionych 18 lat (dane na koniec grudnia 2008 r.) sprywatyzowano bezpośrednio 2105 przedsiębiorstw państwowych oraz 388 spółek, z majątku zaś sprywatyzowanych i zlikwidowanych przedsiębiorstw państwowych utworzono 1560 spółek bez udziału Skarbu Państwa. Oznacza to wymknięcie się spod ewentualnego nadzoru archiwalnego ponad 4 tys. jednostek organizacyjnych, których spuścizna świadczy wszak nadal o polskiej gospodarce narodowej ${ }^{9}$. Na tym jednak nie koniec. Powstały przedsiębiorstwa nowe, które często są największym pracodawcą w powiecie, mieście czy województwie. Jeszcze inne wprowadzają innowacje, zarówno technologiczne, jak i organizacyjne, transmitujące kulturę do małych społeczeństw i przez to stające się bardziej wpływowe od telewizji, radia, Internetu czy prasy.

Pod nadzorem archiwalnym w 2008 r. znajdowało się 9795 aktotwórców (średnio 325 na jedno archiwum) ${ }^{10}$, których dokumentacja kiedyś zostanie

7 K. Popper, Spoteczeństwo otwarte i jego wrogowie, t. 2, tłum. H. Krahelska, oprac. A. Chmielewski, Warszawa 1993, s. 283.

8 W ostatnim czasie do krytyki nadmiernego wpływu archiwów państwowych na działalność biurową aktotwórców, która przetoczyła się przez środowisko archiwalne już na początku lat sześćdziesiątych XX w., powrócił Robert Degen, zob. np. R. Degen, Kancelarie i archiwiści. Garść uwag na temat wptywu pracowników archiwów państwowych na mechanizmy pracy biurowej administracji w Polsce po 1918 roku, [w:] Dzieje biurokracji na ziemiach polskich, t. 2, red. A. Górak, D. Magier, Lublin-Siedlce 2009, s. 267-277.

9 Maty rocznik statystyczny, R. 52, Warszawa 2009, s. 475-476.

10 Roczne sprawozdanie statystyczne Archiwów Państwowych za 2008 r., za: http:// www.archiwa.gov.pl/images/stories/Aktualnosci/KN_1_2008B.pdf [dostęp 5 grudnia 2011 r.]. 
przejęta do zasobu archiwów państwowych. Stanowi to 11\% podmiotów publicznych w Polsce ${ }^{11}$. Jaki jest to jednak wycinek całości działalności podejmowanej przez ludność na terenie Polski w chwili obecnej? Można to sobie uświadomić, przytaczając choćby liczbę 3757093 podmiotów gospodarki narodowej widniejących w rejestrze REGON ${ }^{12}$. Proste działanie matematyczne uzmysławia, że - uznawana z samozadowoleniem za optymalną - polityka selekcji archiwalnej prowadzona obecnie zapewnia zachowanie jedynie $0,2 \%$ spuścizny zarejestrowanych jednostek organizacyjnych funkcjonujących w różnych sferach życia społeczno-gospodarczego w Polsce. Dodajmy do tego działające poza obszarem nadzoru archiwalnego społeczne niesformalizowane organizacje i kluby, niekiedy powstające bardzo spontanicznie, by rozwiązać jakiś konkretny problem społeczny, oraz osoby fizyczne zajmujące się gromadzeniem różnorakich kolekcji czy zbiorów, a otrzymamy rzeczywistą skalę rozdźwięku pomiędzy narodowym a państwowym zasobem archiwalnym A.D. 2009. Gdyby przyjąć, że zabezpieczenie materiałów archiwalnych 10\% funkcjonujących jednostek organizacyjnych to wielkość dostateczna do zachowania źródeł historycznych na temat życia państwa i społeczeństwa (a na takim mniej więcej poziomie jest obecnie utrzymana selekcja aktotwórców publicznych), to dla utrzymania równowagi między państwowym i prywatnym zasobem archiwalnym oznaczałoby potrzebę dodatkowego zarejestrowania materiałów archiwalnych wytwarzanych przez ponad 350 tys. aktotwórców tworzących zasób niepaństwowy. Jak na możliwości archiwów państwowych jest to liczba astronomiczna, oznaczająca ponad 350\% wzrost liczby jednostek organizacyjnych przypadających średnio do monitorowania na jedno archiwum państwowe.

11 Według bazy danych JOPIS (jednostki organizacyjne państwowe i samorządowe), która stanowi, aktualizowany co kwartał, wyciąg sporządzany na potrzeby archiwów państwowych z komputerowego rejestru urzędowego podmiotów gospodarki narodowej REGON prowadzonego przez Główny Urząd Statystyczny, na terenie Polski na początku 2009 r. funkcjonowało ogółem 88167 jednostek organizacyjnych znajdujących się w gestii państwa lub samorządu.

12 Maty rocznik, s. 484, 486. 


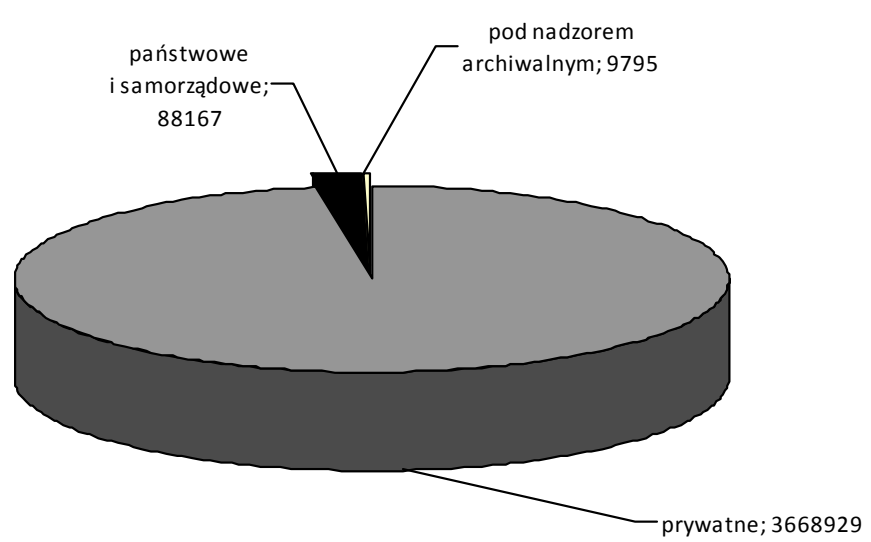

Wykres 1. Podmioty organizacyjne w Polsce na podstawie rejestru REGON na tle nadzoru archiwalnego

Jak wygląda natomiast skuteczność archiwów państwowych w pozyskiwaniu materiałów archiwalnych wytworzonych przez jednostki spoza nadzoru archiwalnego? W ostatnich trzech latach (2006-2008) średnio przejmowano do zasobu jednego archiwum państwowego około 65 zespołów rocznie, z tego tylko siedem pochodziło spoza nadzorowanych jednostek organizacyjnych, stanowiąc z reguły dary osób prywatnych i podmiotów oraz zespoły zakupione $^{13}$. Przy czym najlepiej wygląda pozyskiwanie takich materiałów na szczeblu centralnym, a zatem dokumentacji o znaczeniu ogólnokrajowym. Gdy pominiemy Archiwum Akt Nowych, procent materiałów archiwalnych przejmowanych rocznie spoza jednostek objętych nadzorem archiwalnym wśród ogółu nabywanych zespołów i zbiorów spada z 11 do 7,5. Oznacza to, że aktywność prywatnych podmiotów i kolekcjonerów w terenie wzbudza jeszcze mniejsze zainteresowanie selekcjonerów.

Rekapitulując - przedpole archiwalne, na którym skoncentrował się nadzór państwowej administracji archiwalnej w ciągu ostatniego dwudziestolecia, skurczyło się niepomiernie. Swoją politykę „wszechwładzy” w zakre-

13 Obliczenia własne na podstawie ankiety dotyczącej nabytków, przeprowadzonej w sierpniu i wrześniu 2009 r. Na ankietę odpowiedziało 21 z 30 archiwów. W tym miejscu składamy serdeczne podziękowania za informacje archiwom państwowym w Białymstoku, Bydgoszczy, Elblągu, Kaliszu, Koszalinie, Krakowie, Lesznie, Lublinie, Łodzi, Olsztynie, Piotrkowie Trybunalskim, Płocku, Przemyślu, Rzeszowie, Suwałkach, Szczecinie, Toruniu, Warszawie, Zamościu, Zielonej Górze oraz Archiwum Akt Nowych. 
sie działalności kancelaryjnej oraz szczegółowość ocierającej się ad absurdum kontroli nad biurowością suwerennych wszak jednostek organizacyjnych okupiono ogromem wysiłku etatowego, również kosztem innych dziedzin działalności archiwów, w tym śledzenia niepaństwowego narodowego zasobu archiwalnego.

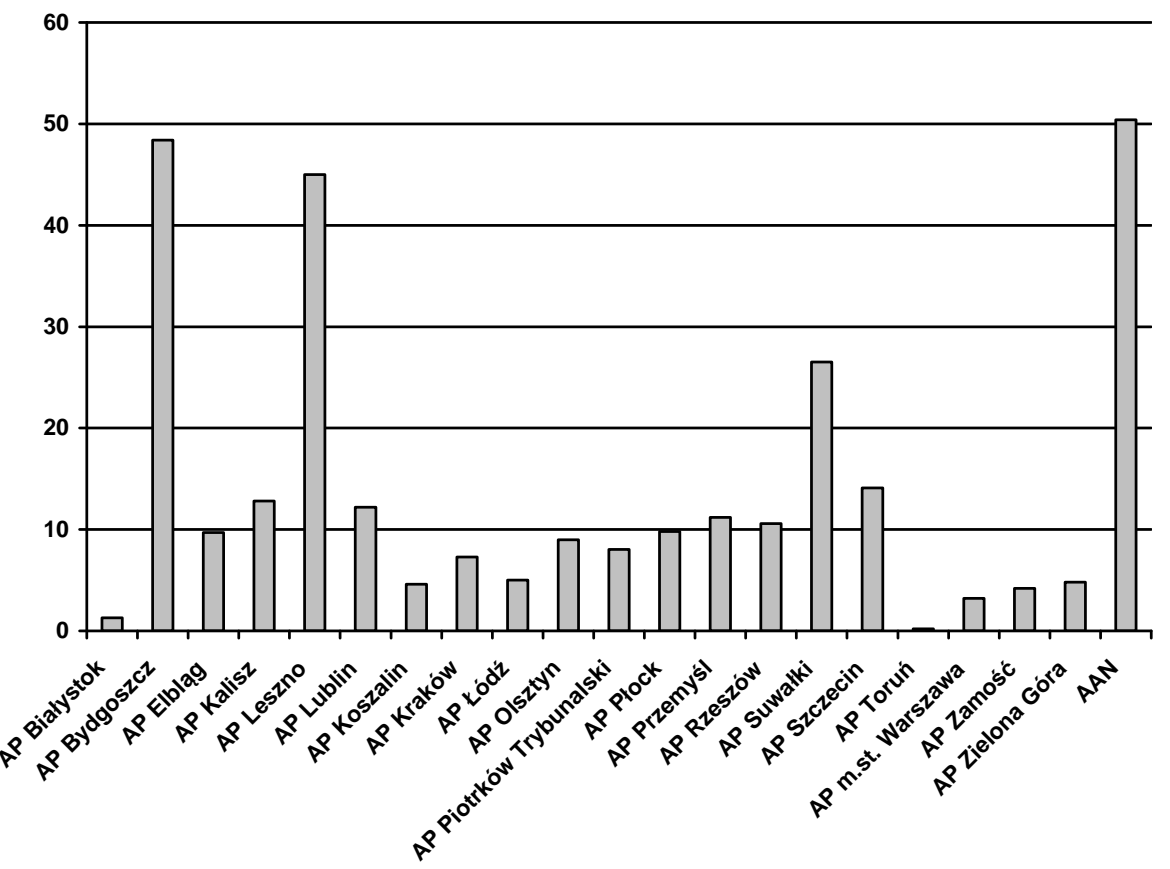

Wykres 2. Procentowy udział materiałów archiwalnych przejmowanych do wybranych archiwów państwowych spoza nadzoru archiwalnego wśród ogółu nabytków tych archiwów w latach 2006-2008 ${ }^{14}$

Pomimo tego wysiłku można stwierdzić, że w chwili obecnej nadzór ten obejmuje - by posłużyć się przeniesionym z języka angielskiego podziałem aktywności społeczno-gospodarczej - niemal wyłącznie pierwszy sektor, czyli administrację publiczną (państwową i samorządową), i śladowo sektor drugi (biznes). Natomiast właściwie poza zainteresowaniem pozostaje sektor trzeci, czyli organizacje społeczne (pozarządowe) typu non profit, nieformalne oraz osoby fizyczne. Tymczasem liczba tych ostatnich, nierzadko wyprzedzających

14 Obliczenia własne na podstawie ankiety. 
w swej aktywności (czy wręcz przejmujących ich zadania) jednostki administracji publicznej, wynosi blisko 60 tys. stowarzyszeń (bez Ochotniczych Straży Pożarnych) oraz ponad 9 tys. fundacji. W dodatku przyrost organizacji społecznych jest wciąż wysoki i sięga około 3 tys. rocznie ${ }^{15}$. Znaczenie tych podmiotów we współczesnym państwie wynika z samej ich definicji, mówiącej o zaspokajaniu różnorakich potrzeb poszczególnych grup społecznych ${ }^{16}$. Ich działalność to najważniejszy wyznacznik tzw. społeczeństwa obywatelskiego, stanowiącego tę część przestrzeni społecznej, która jest autonomiczna wobec państwa i złożona z dobrowolnie współpracujących, zrzeszonych jednostek ${ }^{17}$. Być może są to najciekawsze przejawy „obywatelskości”, mogące powiedzieć nam więcej o więziach społecznych i aktywności lokalnych społeczności w tzw. ponowoczesnych społeczeństwach niż badania administracji terenowej. Nie należy też zapominać o działaniach twórców sztuki, nauki, techniki, polityków i przedsiębiorców. Czy archiwa śledzą ich działalność, czy myślą o zabezpieczeniu jej śladów?

A wszystko to przy objętym powszechnym konsensusem założeniu, że źródłem jest wszystko, co pozwala poznać przeszłość ${ }^{18}$, i że każde źródło jest dopuszczalne, ale żadne $\mathrm{z}$ nich nie stanowi autorytetu ${ }^{19}$. W tym rozumieniu zagadnienie masowości dokumentacji może oznaczać jedynie dużą ilość dokumentacji tego samego typu i proweniencji - nigdy wielość (różnorodność) jej twórców. Tymczasem problemem współczesnej selekcji wydaje się „nadprodukcja” źródeł wtórnych, pochodzących od jednego twórcy, niosących informacje nieweryfikowalne i wielokroć prowadzące do szumu informacyjnego. Wielość twórców i ich produkcji aktowej to w przyszłości rozwój heurystyki i w ogóle nauki historycznej oraz lepsze możliwości do odkrywania prawdy historycznej. Pamiętajmy, że pewne rodzaje źródeł zanikają lub już zanikły. Jak będzie wyglądać podstawa źródłowa historyka bez pamiętników i korespondencji? Co ją zastąpi? Czy kadry archiwów państwowych zastanawiają się nad tym problemem?

15 Trzeci sektor $i$ liczba organizacji, za: http://civicpedia.ngo.pl/x/328111\# [dostęp 5 grudnia 2011 r.]; A. Soboń-Smyk, 20 lat III sektora $w$ Polsce - kilka faktów z badań, za: http://civicpedia.ngo.pl/ngo/459472.htm [dostęp i pobrane 3 września 2009 r.].

${ }_{16}$ Zob. Z. Lasocik, Kilka uwag o roli organizacji pozarzadowych w pañstwie demokratycznym, Warszawa 1994.

17 A. Antoszewski, Spoteczeństwo obywatelskie a proces konsolidacji demokracji, [w:] Studia z teorii polityki, t. 3, red. A. Czajkowski, L. Sobkowiak, Wrocław 2000, s. 9.

${ }_{18}$ Zob. J. Topolski, Metodologia historii, Warszawa 1984, rozdz. XVI.

19 K. Popper, Addendum, [w:] tenże, Spoteczeństwo otwarte, s. 389. 
Obowiązująca ustawa archiwalna (zwana w niektórych kręgach „wiecznie żywą”) obrazuje pewien idealny system produkcji źródeł historycznych, który w latach osiemdziesiątych państwowa administracja archiwalna - gdyby chciała - była w stanie w znacznym stopniu opanować. Jednakże nawet wówczas nie wprowadzono w życie zapisu o ewidencjonowanym niepaństwowym zasobie archiwalnym ${ }^{20}$. O ile jednak w PRL-u życie społeczeństwa było organizowane (i nadzorowane) przez państwo, co oznacza, że jego obraz można będzie odtwarzać za pomocą spuścizny aktowej instytucji państwowych (np. administracji terenowej i gospodarczej, sądowej, milicji obywatelskiej) oraz partii komunistycznej, o tyle sytuacja po 1990 r. przedstawia się już zgoła inaczej. Chociaż ogólny system tworzenia materiałów archiwalnych nakreślony w ustawie z 1983 r. nadal oddaje rzeczywistość, to pozostawienie odpowiedzialności za tę część narodowego zasobu archiwalnego, która ma - jak to ujmuje ustawa - „znaczenie jako źródło informacji o wartości historycznej o działalności Państwa Polskiego, jego poszczególnych organów i innych państwowych jednostek organizacyjnych oraz o jego stosunkach z innymi państwami, o rozwoju życia społecznego i gospodarczego, o działalności organizacji o charakterze politycznym, społecznym i gospodarczym, zawodowym i wyznaniowym, o organizacji i rozwoju nauki, kultury i sztuki, a także o działalności jednostek samorządu terytorialnego i innych samorządowych jednostek organizacyjnych" 21 , jedynie w rękach archiwów państwowych nie dowodzi w chwili obecnej wydolnej polityki archiwalnej. Martwy zapis o ewidencjonowanym niepaństwowym zasobie archiwalnym, czyli materiałach archiwalnych powstałych i powstających w wyniku działalności partii politycznych, organizacji politycznych, spółdzielczych i innych organizacji społecznych, Kościołów i związków wyznaniowych oraz wszystkich innych niepaństwowych i niesamorządowych jednostek organizacyjnych ${ }^{22}$, wyklucza spośród przyszłych źródeł archiwalnych większość dokumentacji, która mogłaby oddać pełnię informacji o współczesnej Polsce i jej mieszkańcach. Problem polega na tym, że tego zapisu nie da się wprowadzić w życie! Po prostu tej kolejnej sfery nie „skonsumowałby” i tak przeciążony system nadzoru archiwalnego.

Widać zatem wyraźnie, że potrzeba tu zupełnie innych rozwiązań w zakresie selekcji archiwalnej niż funkcjonujące obecnie. Niestety, trudno od-

20 Ustawa o narodowym zasobie archiwalnym i archiwach z 14 lipca 1983 r., art. 42 (tekst jednolity DzU 2006, nr 97, poz. 672 i 673).

21 Tamże, art. 1.

22 Tamże, art. 42. 
naleźć je również w projekcie nowej ustawy archiwalnej, która powiela dotychczasowe założenia dotyczące rejestrowania materiałów archiwalnych wytwarzanych przez prywatne jednostki organizacyjne ${ }^{23}$. Oznacza to dalsze zrzucanie ciężaru selekcji wyłącznie na archiwa państwowe i trudno oczekiwać, by sprostały one temu zadaniu, skoro nie radziły sobie z nim dotychczas. Pewnym novum jest obowiązek zgłaszania do rejestru materiałów archiwalnych partii politycznych, których przedstawiciele uzyskali mandat posła lub senatora ${ }^{24}$. W czasach niewielkiego, pozaparlamentarnego wpływu partii politycznych na życie społeczne nie stanowi to jednak radykalnego kroku naprawczego, lecz kontynuację rzeczywistości z poprzedniej epoki, kiedy monopartia organizowała życie ludzi. Zaprojektowano, że inne podmioty niepubliczne, jeśli przechowują materiały archiwalne, „mogą zgłosić je do rejestru" 25 . Skąd jednak będą miały wiedzę o tym, że takie materiały przechowują? Poza tym, wygląda to tak, jakby to tym jednostkom miało zależeć na zachowaniu spuścizny historycznej, a nie strukturze powołanej specjalnie do tego celu. Można przeto obawiać się, że nowa ustawa nie tylko nie rozwiązuje problemu wymykających się przyszłym historykom źródeł archiwalnych, ale wręcz sankcjonuje stan obecny. Zupełnie zaś (świadomie ${ }^{26}$ ) pomija zbiory gromadzone przez osoby fizyczne (zbiory i spuścizny).

Wszystkie nasze dotychczasowe rozważania odnoszą się do sytuacji niemal zupełnego zrzucania problemu kształtowania narodowego zasobu archiwalnego na barki archiwów państwowych (wyjątkiem są nieliczne, zgodnie zresztą z obowiązującą ustawą archiwalną, spełniające tę funkcję biblioteki i muzea). Już jednak przed kilkoma laty Alicja Kulecka stwierdziła, że „dla środowiska historycznego, jako grupy zawodowej zainteresowanej $\mathrm{w}$ sposób szczególny archiwami, ważny jest również problem odpowiedzialności za gromadzenie oraz organizację tej czynności”"27. Może więc czas, by państwowa administracja archiwalna skorzystała $\mathrm{z}$ tego wsparcia $\mathrm{w}$ dziedzinie selekcji i gromadzenia materiałów archiwalnych. Z projektu nowej ustawy archiwalnej wynika wyraźnie, że uniwersum archiwów państwowych to

23 Prawo o postępowaniu z dokumentacja i o archiwach-projekt z 15 I 2009 r., za: http://www.mkidn.gov.pl/docs/postep_dokumentacja_i_archiwa.pdf [dostęp i pobrane 3 września 2009 r.].

24 Tamże, art. 18, ust. 4, pkt 4.

25 Tamże, ust. 5.

26 Tamże, „Ocena skutków regulacji” dołączona do projektu ustawy.

27 A. Kulecka, Teoria gromadzenia a problemy wspótczesności i przysztości, tekst wystąpienia na 17. Powszechnym Zjeździe Historyków Polskich, za: http://jazon.hist.uj.edu.pl/zjazd/materialy/kulecka.pdf, s. 9 [dostęp 5 grudnia 2011 r.]. 
w zasadzie tylko narastający zasób państwowy i samorządowy. Bez dociekania zasadności tego trendu, nadzorowi nad jednostkami państwowymi i samorządowymi będzie poświęcać się przypuszczalnie coraz więcej czasu i wysiłku, a archiwa państwowe zaczną przeradzać się wyłącznie w branżową administrację archiwalną (organ państwowej administracji specjalnej o przewadze kompetencji nadzorczych czy policję archiwalną? ${ }^{28}$ ) dla publicznych jednostek organizacyjnych. Trudno, by wobec tego były one w stanie nadzorować całokształt narodowego zasobu archiwalnego. Będzie to oznaczać trwanie absurdalnej sytuacji, w której archiwiści państwowi w pocie czoła trwonią czas na debatowanie nad tym, czy słuszne, czy też nie, jest wybrakowanie jakiejś teczki zawnioskowanej w spisie dokumentacji niearchiwalnej, której okres przechowywania upłynął, przez publiczny podmiot organizacyjny, podczas gdy bezpowrotnie giną lub ulegają rozproszeniu setki metrów bieżących pierwszorzędnej dokumentacji mogącej stanowić źródła historyczne, wytworzonej przez prywatne osoby prawne i zgromadzone przez osoby fizyczne. Zachowanie status quo w zakresie selekcji archiwalnej będzie oznaczać trwanie owego mentalnego ograniczenia każącego uznawać za materiały archiwalne przede wszystkim dokumentację administracji państwa i samorządu terytorialnego.

Nadzieje na rozwiązanie tego problemu wiążemy z nowym podmiotem zaproponowanym przez projekt prawa archiwalnego - archiwum historycznym. Skoro archiwum historyczne ma mieć taki sam zakres działalności jak archiwum państwowe ${ }^{29}$, a obligatoryjnie archiwami historycznymi stają się biblioteki i muzea ${ }^{30}$, dlaczegóż od razu nie wskazać kilkuset takich placówek, obejmujących swoim zasięgiem obszar jednego-dwóch powiatów, nie wyposażyć je we wszelkie prerogatywy pozwalające im na to, by zajęły się kontaktami, pozyskiwaniem i gromadzeniem (a zatem również selekcją) tej części narodowego zasobu archiwalnego, który powstaje w kancelariach podmiotów prywatnych bądź też został zgromadzony przez osoby fizyczne. Któż bowiem, jak nie placówki funkcjonujące w środowiskach lokalnych, w realiach zdecentralizowanego państwa i rozbudowy wspomnianego już społeczeństwa obywatelskiego, prawidłowo przeprowadzi selekcję twórców materiałów ma-

28 Ikonka przedstawiająca policjanta w stylu angielskim, z pałką, widniała zresztą w którejś wersji elektronicznej bazy danych zbierającej informacje dotyczące nadzoru archiwalnego, co może doskonale świadczyć o samookreślaniu się archiwistów pracujących w nadzorze (oraz wymogach, jakie stawia im organ nadrzędny).

29 Prawo o postępowaniu $z$ dokumentacją, art. 40.

30 Tamże, art. 83, ust. 1, pkt 4. 
jących znaczenie dla dziejów miejscowych społeczności? Można by tu wykorzystać np. sieć bibliotek publicznych, które - przy pomocy historyków - efektywnie mogłyby pozyskiwać dokumentację do narodowego zasobu archiwalnego. Kwestia miejsca ich przechowywania jest już drugorzędna i zależna od możliwości organizacyjnych oraz zatrudnienia odpowiedniej liczby archiwistów. Skala kształcenia archiwalnego w Polsce nie rodzi raczej zagrożenia niesprostania temu zadaniu. Korzyścią nie do przecenienia byłoby natomiast włączenie materiałów archiwalnych przechowywanych w muzeach i bibliotekach (jako archiwach historycznych) do systemu informacyjnego narodowego zasobu archiwalnego.

Powyższe rozważania zakładają, oczywiście, w pewnym sensie rewolucję w dziedzinie archiwalnej. Przewidują bowiem odebranie archiwom państwowym dotychczasowego monopolu w zakresie selekcji aktotwórców oraz dokumentacji. Czyż jednak już dzisiaj - jak zauważa Halina Robótka (z dezaprobatą) - archiwa nie pozbywają się tych zadań, cedując kwalifikację archiwalną akt na promotorów na uczelniach czy też prokuratorów i sędziów? ${ }^{31}$ W tym przypadku, odmiennie od powyższego przykładu, selekcja nadal pozostawałaby częścią ars archivistica. Kwestia, czy te funkcje będą wykonywać archiwiści z archiwów państwowych, czy też archiwiści z bibliotek bądź muzeów realizujących zadania archiwów historycznych, w obliczu problemu sprostania ogromowi narastającego narodowego zasobu archiwalnego jest już doprawdy obojętna.

Ogólna konkluzja jest smutna: działalność archiwalna stała się bezrefleksyjnym urzędowaniem, czasem komercyjną usługą, ale nie służbą publiczną służbą na rzecz kultury narodowej. Znowu zatem wracamy do podstaw. Oto bowiem problem polega nie - jak mogłoby się wydawać - na zagospodarowywaniu nowych typów źródeł, lecz na realizowaniu starych standardów misji archiwalnej.

\section{Appraisal process as an element of historical resource development}

\section{Summary}

The authors assume that the effects of the mechanism that is currently used to develop the archival resources in Poland are not able to meet the needs of historical sciences. They point out the reasons for this situation and come to conclusion that archival activity in Poland has become a thoughtless office chore, sometimes even a commercial service, and is not a public service any more - that is, a service for the benefit of the na-

31 H. Robótka, dz. cyt., s. 6. 
tional culture. When it comes to development of the archival resources, the solution is not to introduce new types of sources, but to continue implementing the old standards of the mission to collect and preserve archival materials. 